\title{
GROUND-WATER-QUALITY DATA FOR ALBANY AND SURROUNDING AREAS, SOUTHWEST GEORGIA, 1951-99
}

by Debbie Warner, Jaime A. Easoz, and Sherlyn Priest

U.S. GEOLOGICAL SURVEY

OPEN-FILE REPORT 02-124

Prepared in cooperation with

ALBANY WATER, GAS, AND LIGHT COMMISSION 


\section{U.S. DEPARTMENT OF THE INTERIOR \\ GALE A. NORTON, Secretary}

U.S. GEOLOGICAL SURVEY

CHARLES G. GROAT, Director

For additional information write to:

State Representative

U.S. Geological Survey

Peachtree Business Center

3039 Amwiler Road, Suite 130

Atlanta, Georgia 30360-2824
Copies of this report can be purchased from:

U.S. Geological Survey

Branch of Information Services

Box 25286

Federal Center

Denver, CO 80225 


\section{CONTENTS}

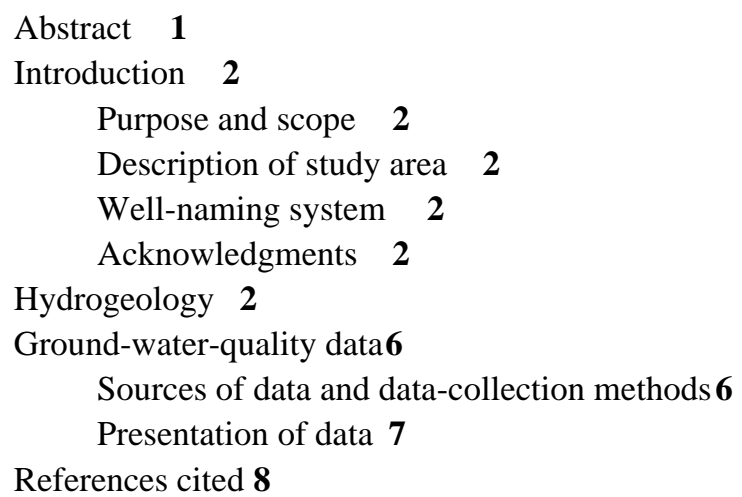

\section{ILLUSTRATIONS}

Figures 1a,b. Maps showing location of:

1a. Study area and ground-water-quality sampling sites in Albany, Georgia and surrounding areas $\mathbf{3}$

1b. Ground-water-quality sampling sites in Dougherty County, Georgia 4

Figure 2. Generalized stratigraphy and water-bearing properties of formations underlying Albany and surrounding areas, southwest Georgia 5

\section{VERTICAL DATUM}

In this report "sea level" refers to the National Geodetic Vertical Datum of 1929 (NGVD of 1929)—a geodetic datum derived from a general adjustment of the first-order level nets of both the United States and Canada, formerly called "Sea Level Datum of 1929."

\section{HORIZONTAL DATUM}

Projection information for the data presented on the maps is as follows:

\begin{tabular}{lll}
\hline Projection $=$ & Albers Euqal-Area \\
Units & Meters \\
Datum $=$ & North American Datum \\
& of 1983 or GRS 1980 \\
Parameters $=$ & Central Meridian: & \\
& 1st Standard Parallel: & -833000 \\
& 2nd Standard Parallel: & 293000 \\
& Reference Latitude: & 453000 \\
& False Easting: & \\
& False Northing: & 0.0000 \\
& & 0.00 \\
\hline
\end{tabular}




\title{
GROUND-WATER-QUALITY DATA FOR ALBANY AND SURROUNDING AREAS, SOUTHWEST GEORGIA, 1951-99
}

\author{
by Debbie Warner, Jaime A. Easoz, and Sherlyn Priest
}

\begin{abstract}
This report presents ground-water-quality data from the surficial, Upper Floridan, Claiborne, Clayton, and Upper Cretaceous aquifers in the Albany and surrounding areas of southwest Georgia. Water-quality data from about 186 wells in Baker, Calhoun, Dougherty, Lee, Mitchell, Terrell, and Worth Counties are presented for the period from 1951 through 1999. The data include field water-quality parameters collected during 1951-99, volatile and semi-volatile organic compounds collected during 1981-97, inorganic compounds collected during 1951-99, trace metals collected during 1964-99, radiochemicals collected during 1993-95, herbicides and insecticides collected during 1980-97, and recovery data for laboratory surrogate compounds (used for quality control
\end{abstract}

and quality assurance for organic samples) collected during 1993-97. Ground-waterquality data are presented in tables by data type and arranged by well number.

Illustrations in this report contain information about study area location, well location, stratigraphy, and formation water-bearing properties. Ground-water-quality data are presented in text files and in a data base that includes geographic and tabular data. Data presented in this report provide a base with which to better define and interpret the quality of ground water in Albany, Ga., and surrounding areas. Although some of these data may have been published in previous reports associated with water-resources investigations, water-quality data are compiled as a useful resource. 


\section{INTRODUCTION}

Concern over the protection of water supply from the Upper Floridan, Claiborne, Clayton, and Providence aquifers has prompted the Albany Water, Gas, and Light Commission (WGL) to monitor the long-term groundwater quality in these aquifers. The U.S. Geological Survey (USGS), in cooperation with WGL, has collected ground-water samples for water-quality analyses in the Albany area since 1951. Some of these water-quality data have been published in interpretive reports, but these reports generally do not present all data collected during a study. This report provides a compilation and documentation of ground-water-quality data for the Albany and surrounding areas of southwest Georgia for 1951-99.

\section{Purpose and Scope}

This report presents ground-water-quality data collected from 186 wells in Baker, Calhoun, Dougherty, Lee, Mitchell, Terrell, and Worth Counties from 1951-99 (fig. 1a; wells in Dougherty County are identified in fig. 1b). The frequency of data collection and types of water-quality analyses vary according to the various objectives of the water-resources investigations conducted throughout the period 1951-99. Wellconstruction and water-quality data are grouped by data type and arranged by well number. These data are presented as text files in an ArcView Geographic Information System (GIS) data base that includes geographic and tabular data. The ArcView format allows a user to view the data spatially and query the data of interest; and allows a user without access to ArcView to view the data tables through a text format.

\section{Description of Study Area}

The Albany, Ga., area is located in southwestern Georgia in the Coastal Plain physiographic province (fig. 1a). Seven counties-Baker, Calhoun, Dougherty, Lee, Mitchell, Terrell, and Worth—comprise the generally flat to gently rolling study area. The area is characterized by karst topography and marked by numerous sinkholes (Hicks and others, 1987).

Land use in the study area is predominantly agricultural and residential. Agricultural areas include cropland, pasture, orchards, and nurseries. Residences primarily use private septic-tank systems. Various use industries are located in and around the Albany city limits (Stewart and others, 1999).

\section{Well-Naming System}

In this report, wells are numbered using a system based on USGS 7-1/2-minute topographic quadrangle maps. Each topographic map in Georgia has been assigned a number and letter designation beginning at the southwestern corner of the State. Numbers increase eastward through 39; letters advance northward through "Z," then double-letter designations "AA" through "PP" are used. The letters "I," "O," "II," and "OO" are not used. Wells inventoried in each quadrangle are numbered sequentially beginning with " 1 ." Thus, the $123^{\text {rd }}$ well inventoried in the Baconton North quadrangle (designated 12K) in Dougherty County is designated as well $12 \mathrm{~K} 123$.

\section{Acknowledgments}

Special thanks goes to Mr. Lemuel O. Edwards, General Manager of the Albany Water, Gas, and Light Commission, for support and assistance. Appreciation also is extended to the many cordial land owners who allowed access to their properties for data collection throughout the period 1951-99. The authors also thank the many individuals from the USGS who assisted in the successful completion of this report.

\section{HYDROGEOLOGY}

A detailed description of the hydrogeology of the Albany area is beyond the scope of this report.

However, the hydrogeology summarized below is based on previous investigations as cited.

Four principal aquifers supply water to Albany and the surrounding areas. These are, in descending order, the Upper Floridan (locally called the Ocala aquifer and formerly called the principal artesian aquifer), Claiborne (formerly called the Tallahatta), Clayton, and Providence aquifers. The surficial aquifer is not considered a principal aquifer; however, water-quality data from the surficial aquifer (the uppermost aquifer in the area) are included in this report. The Providence aquifer is part of the Upper Cretaceous aquifer system which also includes the Ripley Formation and the upper part of the Cusseta Sand. This report includes data from three wells open to multiple aquifers in the Upper Cretaceous aquifer system and one well open to the Ripley Formation. Generalized stratigraphy and hydrogeology of the Albany and surrounding areas are shown in figure 2 . 


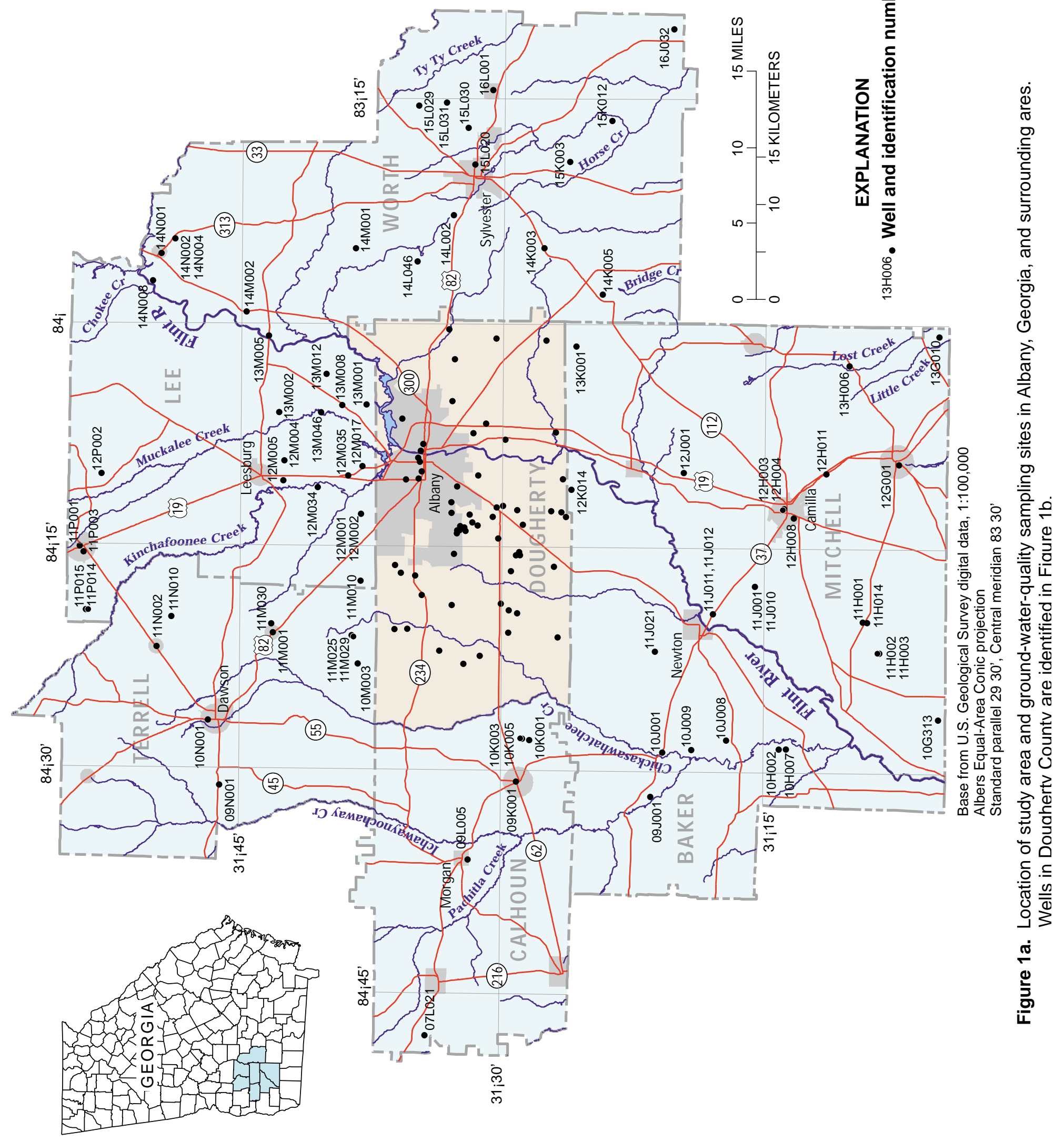




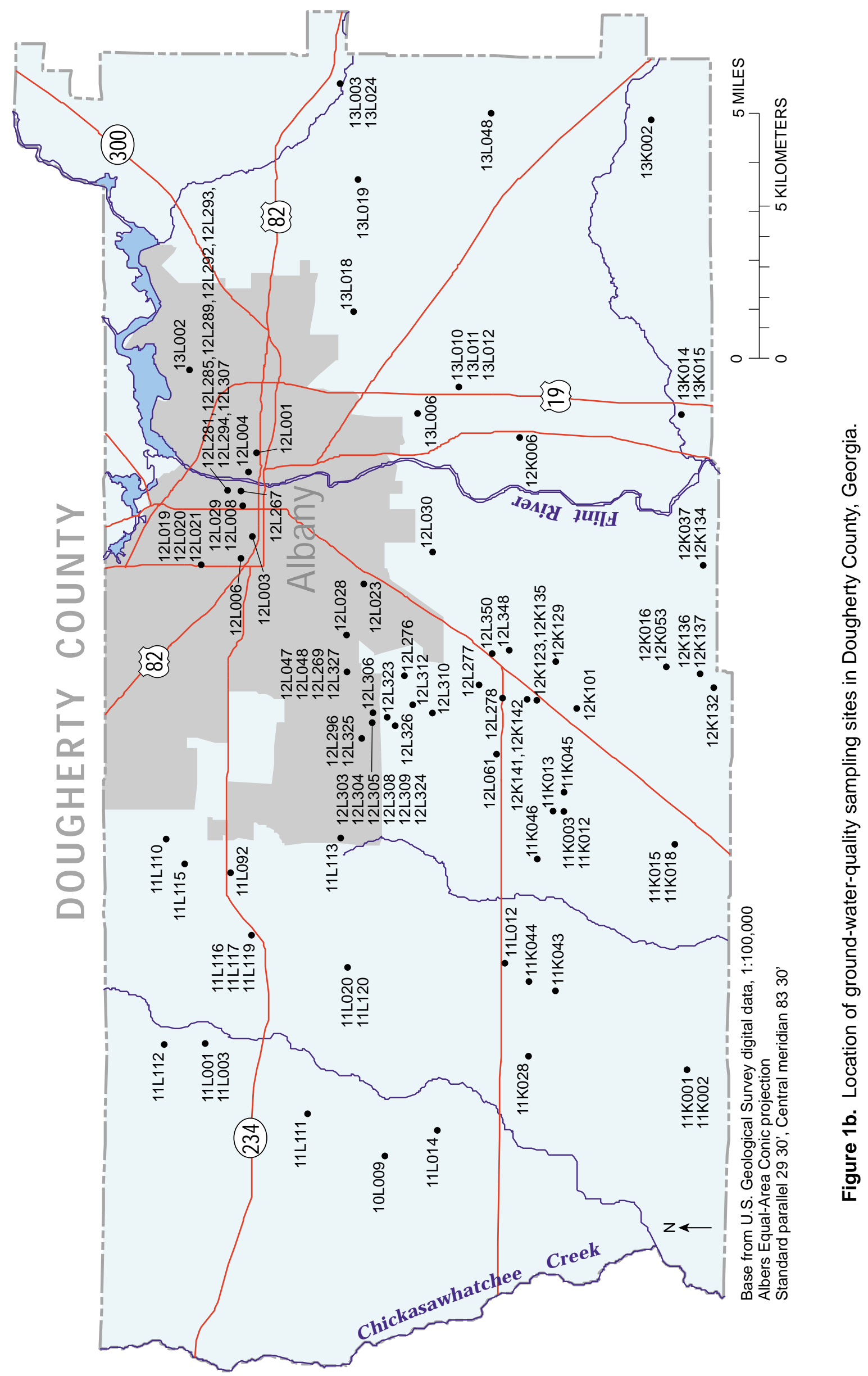




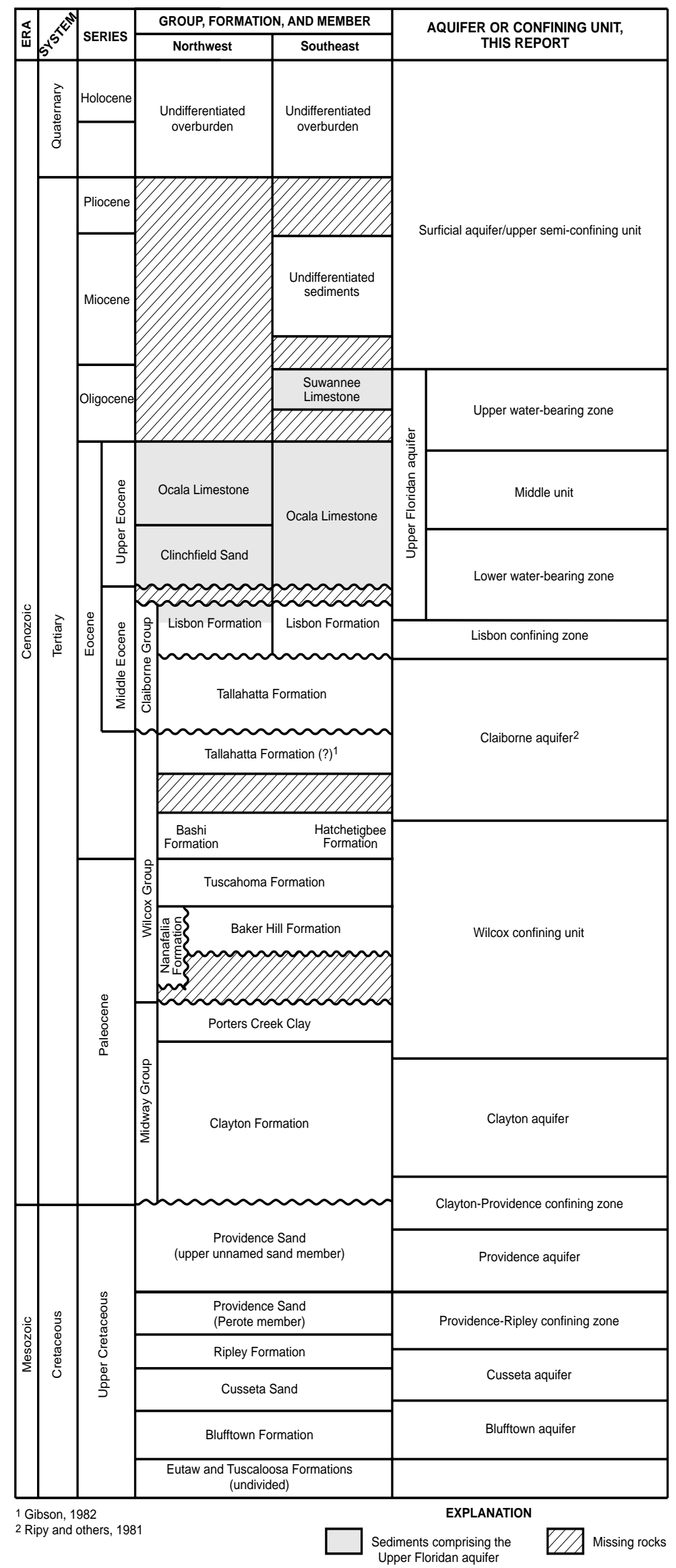

Figure 2. Generalized stratigraphy and water-bearing properties of formations underlying Albany and surrounding areas, southwest Georgia [Modified from Clarke and others, 1984 (early Eocene and older) and Hicks and others, 1987 (middle Eocene and younger)]. 
The surficial aquifer is within the undifferentiated Quaternary overburden, the uppermost hydrogeologic unit in the study area (Hicks and others, 1987). The overburden consists of fine to coarse quartz sand, clayey sand, sandy clay, and clay. At the base of the overburden, a layer of sandy clay and clayey limestone directly overlies the Ocala Limestone. This clayey zone probably is residuum derived from weathering of the Ocala Limestone and comprises the upper semiconfining unit of the Upper Floridan aquifer (Warner, 1997). The sandy zones constitute the surficial aquifer (Warner, 1997).

The Upper Floridan aquifer is a part of the Floridan aquifer system and primarily consists of the upper Eocene Ocala Limestone (Hicks and others, 1981). The Upper Floridan aquifer was subdivided into an upper water-bearing zone, a middle confining unit, and a lower water-bearing zone because of differing hydrologic properties (Hicks and others, 1987). The upper water-bearing zone consists of fossiliferous, weathered, friable, chalky limestone (Stewart and others, 1999). The middle unit consists of relatively impermeable dense, clayey, chalky limestone (Hicks and others, 1987). The middle unit is discontinuous; and therefore, locally absent in parts of the study area. The lower water-bearing zone consists of alternating layers of sandy limestone and recrystallized dolomitic limestone with well-developed secondary permeability along solution-enlarged joints, bedding planes, and fractures (Hicks and others, 1987). The Upper Floridan aquifer is confined below by the middle Eocene Lisbon Formation and semiconfined above by low-permeability sediments of the undifferentiated Quaternary overburden (Warner, 1997). The Upper Floridan aquifer may be unconfined either where the overburden has been breached by erosion or sinkhole collapse has occurred in the Ocala Limestone (Stewart and others, 1999).

The Claiborne aquifer-formerly called the Tallahatta aquifer (Hicks and others, 1981) — is within Eocene strata and consists of fine-to-medium sand and interbedded limestone layers that are fossiliferous at the top of the unit (Hicks and others, 1981). The Claiborne is confined below by the clayey Tuscahoma Formation and above by the upper part of the Lisbon Formation (Hicks and others, 1981). Water in the Claiborne aquifer in the Albany area occurs at depths ranging from about 125 to 350 feet below land surface (Hicks and others, 1981).
The Clayton aquifer is within lower Paleocene strata and consists of fine-to-medium, arkosic, locally glauconitic, silty sand overlain by massive, light-gray, recrystallized, fossiliferous limestone which, in turn, is overlain by fine-to-medium, calcareous quartz sand and interbedded thin limestone (Hicks and others, 1981). The aquifer is confined below by the silty upper Providence-lower Clayton sequence and above by the clayey Tuscahoma Formation (Hicks and others, 1981). Water in the Clayton aquifer in the Albany area occurs at depths ranging from about 550 to 840 feet below land surface (Hicks and others, 1981).

The Providence aquifer is part of the Upper Cretaceous aquifer system (Clarke and Pierce, 1984) and consists of sand with variable amounts of silt, overlain by coquina, which, in turn, is overlain by dense, gray, clayey sand (Hicks and others, 1981). The aquifer is confined below by the dense clay of the Ripley Formation and above by the silty upper Providence-lower Clayton sequence (Hicks and others, 1981). Water in the Providence aquifer in the Albany area occurs at depths ranging from about 640 to 960 feet below land surface (Hicks and others, 1981).

\section{GROUND-WATER-QUALITY DATA}

Water-quality data presented herein include field waterquality parameters, concentrations of volatile and semivolatile organic compounds, inorganic compounds, trace metals, radiochemical compounds and isotopes, herbicides and insecticides, and recovery data for laboratory surrogate compounds. These data show varying contaminant levels detected in ground water; and therefore, may assist in future monitoring of water quality in the study area.

\section{Sources of Data and Data-Collection Methods}

Concerns about meeting increasing water-supply demands and ensuring water-quality standards to be maintaianed in the Albany area have resulted in many water-resources investigations conducted by the USGS in cooperation with WGL and various State of Georgia agencies from the 1950s to the present (2002). Several of these investigations include water-quality analyses. Mitchell (1981) presented climatologic, geologic, and hydrologic data for the Albany area and compared the water quality of the Claiborne aquifer to the Upper Floridan aquifer. Hayes and others (1983) reported on the hydrology of the Upper Floridan aquifer and published major inorganic constituent and pesticide data for selected wells in the Dougherty Plain District. Hicks and others $(1981,1987)$ described the hydrogeology of 
the Albany area, assessed the ground-water quality of the Upper Floridan aquifer, and evaluated the development potential of the Upper Floridan aquifer.

Water-quality data collected by the USGS are stored in the USGS National Water Information System (NWIS) Water-Quality System (WQ) (http://water.usgs.gov/pubs/FS/FS-027-98/; USGS (2002) website accessed on March 4, 2002). The WQ System contains results of more than 3.5 million water-sample analyses that describe the chemical, physical, biological, and radiochemical characteristics of both surface and ground water nationwide. Types of chemical data include filtered and unfiltered concentrations of major ions, trace elements, nutrients, pesticides, base-neutral organics, acid organics, and volatile organic compounds. Physical characteristics data include $\mathrm{pH}$, specific conductance, water and air temperature, dissolved oxygen, barometric pressure, and percent dissolved oxygen saturation.

Water samples are analyzed at various laboratories equipped to perform chemical analyses ranging from determinations of simple inorganic compounds, such as chlorides, to complex organic compounds, such as pesticides. As each analysis is completed, results are verified by laboratory personnel and returned to the data submitter by computer transmission; and subsequently are stored in the water-quality data base of the submitter. Laboratory analyses of water samples presented in this report were performed by the USGS National Water-Quality Laboratory, Denver, Colo., or the USGS Quality of Water Services Unit, Ocala, Fla.

The WQ system can produce three types of tables of water-quality data and one table of biological population data. Types of summary tables include frequency percentiles, analytical detection limits; sample summary, and alert limits. Several standard output formats, such as flatfile and ascii format, are available for input to applications. The system's graphic outputs include: X-Y plots, regression plots, boxplots, time-series plots, Stiff diagrams, and Piper diagrams.

\section{Presentation of Data}

Water-quality data on this CDROM are presented in tables by data type, and arranged by well number and date. All of the data tables are text files. Wellconstruction data for all wells are provided in the file "well_construction.txt." "Fieldparam.txt" presents field water-quality parameters from 160 wells collected from 1951-99. "Volorg.txt" presents volatile and semi volatile organic compounds from 73 wells collected from 1981-97. "Inorgan.txt" presents inorganic compounds from 165 wells collected from 1951-99; 33 wells in this file contain inorganic compounds in concentrations above the U.S. Environmental Protection Agency (EPA) maximum contaminant level (MCL) or secondary maximum contaminant level (SMCL) (http://www.epa.gov/safewater/consumer/mcl.pdf; EPA (2001) website accessed June 4, 2001).

"Metals.txt" presents trace metals collected from 124 wells from 1964-99; 50 wells in this file contain trace metals in concentrations above the MCL or SMCL. "Radchem.txt" presents radiochemicals collected from 23 wells from 1993-95. "Pest.txt" presents herbicides and insecticides collected from 86 wells from 1980-97; two wells in this file contain herbicides or insecticides in concentrations above the MCL or SMCL. "Orgqaqc.txt" presents recovery data for laboratory surrogate compounds (used for organic sample quality control and quality assurance) collected from 57 wells from 1993-97. Each data table has a corresponding heading table in which all abbreviations are defined. For example, the file "field_headings.txt" contains definitions for all abbreviations found in the file "fieldparam.txt."

Duplicate and blank water samples were used to evaluate data quality. Duplicate samples were collected to check the precision of the sample analyses in the laboratory and can be obtained through NWIS. Blank water samples were collected to check for field-collection contaminants. Field blanks were reported only if a parameter was detected during analysis. Blank water samples are reported for well $10 \mathrm{~J} 008$ in 1994; $11 \mathrm{~K} 045$ in 1994; $11 \mathrm{~L} 003$ in 1992; $12 \mathrm{~K} 133$ in 1995; 12L 277 in 1997; 12M017 in 1996; 12M034 in 1994; 14N004 in 1995; and 14N008 in 1993.

Water-quaity samples determined by the laboratory to be below contaminant detection limits are designated with a minus sign (-) followed by the value of the detection limit at the time of analysis. If the detection limit is unknown, the value -9999 is used for a nondetected value. Significant figures vary according to laboratory precision and USGS reporting guidelines. The period of data collection in the tables varies because several water-resources investigations were conducted over differing time periods. The EPA MCL or SMCL are listed in the heading tables, where applicable, (http://www.epa.gov/unix0008/community_resources/ muni/water/wmcl.html, EPA (2000) website accessed on June 28, 2000). 


\section{REFERENCES CITED}

Clarke, J.S., and Pierce, R.R., 1984, Georgia water facts-ground-water resources in the United States, in National Water Summary, 1984: U.S. Geological Survey Water-Supply Paper 2275, p. 179-184.

Hicks, D.W., Krause, R.E., and Clarke, J.S., 1981, Geohydrology of the Albany area, Georgia: Georgia Geologic Survey Information Circular 57, $31 \mathrm{p}$.

Hicks, D.W., Gill, H.E., and Longsworth, S.A., 1987, Hydrogeology, chemical quality, and availability of ground water in the Upper Floridan aquifer, Albany area, Georgia: U.S. Geological Survey WaterResources Investigations Report 87-4145, 52 p.

Mitchell, G.D., 1981, Hydrogeologic data of the Dougherty Plain and adjacent areas, southwest Georgia: Georgia Geologic Survey Information Circular 58, $124 \mathrm{p}$.

Stewart, L.M., Warner, Debbie, and Dawson, B.J., 1999, Hydrogeology and water quality of the Upper Floridan aquifer, western Albany area, Georgia: U.S. Geological Survey Water-Resources Investigations Report 99-4140, 42 p.

U.S. Environmental Protection Agency, 2001, http://www.epa.gov/safewater/consumer/mcl.pdf: U.S. Environmental Protection Agency website accessed on June 4, 2001.

2002, http://www.epa.gov/unix0008/

community_resources/muni/water/wmcl.html: U.S. Environmental Protection Agency website accessed on March 4, 2002.

U.S. Geological Survey, 2002, http://water.usgs.gov/pubs/FS/FS-027-98/: U.S. Geological Survey website accessed on March 4, 2002.

Warner, Debbie, 1997, Hydrogeologic evaluation of the Upper Floridan aquifer in the southwestern Albany area, Georgia: U.S. Geological Survey WaterResources Investigations Report 97-4129, 27 p. 